УДК 638.124.252.2

(C) 2012

Гречка Г. М., кандидат сільськогосподарських наук

Національний науковий центр «Інститут бджільництва ім. П. І. Прокоповича»

\title{
ОСОБЛИВОСТІ ЖИТТЄЗДАТНОСТІ МЕДОНОСНИХ БДЖІЛ IЗ РОЙОВИМИ МАТКАМИ
}

\section{Рецензент - кандидат сільськогосподарських наук М. О. Шамро}

\begin{abstract}
Охарактеризовані біологічні ознаки весняної життєздатності сімей бджіл із ройовими матками. Зокрема, комплексним оичнюванням зимостійкості встановлено, що найвищим ї̈ потенціалом наділені родини з посаджених роїв. Різниия загального числа ӥх балів і балів сімей, повернених до робочого стану та ройових материнських до не збуджених роїнням, становила, відповідно: 44,4-33,3-11,1\%. Відмічено також зменшення послаблення сили на $45 \%$, витрат корму на 15 і збільшення числа розплоду в перший весняний облік на $9 \%$.
\end{abstract}

Ключові слова: зимостійкість, медоносні бджоли, матки, роїння, розплід.

Постановка проблеми. Розкриття потенційної здатності сімей медоносних бджіл із матками різного способу виведення до раціональної життєдіяльності в кожен конкретний період їх життя, стабілізація та спрямування біологічних ознак бджіл на виробництво продукції - актуальне питання сьогодення. Ефективність роботи пасіки в активний сезон тісно пов'язана 3 підготовкою бджолиних сімей до безоблітного періоду та зимостійкістю. Краще перезимовані бджоли є більш життєздатними, швидше відновлюються та виробляють більше продукції. За якого способу розмноження медоносні бджоли найоптимальніше наділені ознаками бажаної якості, впродовж якого терміну їх матки є фізіологічно життєздатними - важливе селекційне питання, що потребує досконалого вивчення. Ми вирішили порівняти біологічні ознаки весняної життєздатності сімей піддослідних груп, сформованих у минулий пасічний сезон із бджіл посаджених роїв, повернених до робочого стану, ройових материнських, не збуджених роїнням.

Аналіз основних досліджень і публікацій, у яких започатковано розв'язання проблеми. Життя бджолиних родин утворене за складною схемою їх життєдіяльності [1]. Річний цикл життєдіяльності i продуктивність бджіл тісно пов'язані з умовами клімату й медозбору певної географічної зони [4]. В Лісостепу України життєвий річний цикл бджолиних сімей української степової породи впродовж року відмічається се- зонністю. Він представлений чотирма періодами. Перший - підготовчий період - триває 3 часу відкладання маткою перших яєць і до початку збільшення числа бджіл у сім'ї після відмирання зимувалих бджіл (приблизно 3 кінця лютого до середини квітня). Другий період характеризується збільшенням числа бджіл із середини квітня i до кінця липня. Третій період пов'язаний із формуванням зимуючих бджіл. Розпочинається він зі зменшення числа бджіл після головного медозбору з кінця липня до середини вересня. Четвертий період - зміни в бджолиній сім’і впродовж зими до початку відкладання маткою яєць. Зміна чисельності бджіл та їх потенційна спроможність виробляти продукцію упродовж весняно-літнього сезону обумовлена багатьма факторами. Одним із них є якість маток і залежна від неї життєздатність бджолиних сімей [2].

Підвищена потенційна здатність медоносних бджіл до виконання своїх функціональних можливостей, напевно, пояснюється також і особливістю їх походження від родоначальниці в сім'ї, зокрема: матка $\epsilon$ ройовою, свищевою, штучного виведення чи ін. В рої майже кожна бджола володіє всіма потенційними можливостями до льотної роботи, тоді як у звичайній робочій бджолиній сім'ї є багато (до 50 \%) старих бджіл із обмеженими можливостями до польотів за нектаром [5]. Відомо, що темп розвитку сімей із ройовими матками вищий, ніж у сім'ях із матками свищевими та штучно виведеними. Такі сім’ї мають більшу кількість розплоду й молодих бджіл. Оскільки для успішної зимівлі сила нарощених до безоблітного періоду сімей має велике значення, можна передбачити, що зимостійкість та життєздатність родин із ройовими матками будуть досить високими. Наскільки ж вигідні рійливі бджоли і скільки часу зберігається потенціал активної життєздатності ройових сімей досі залишається таємницею.

За контрольованого бджоловедення утримання на пасіках ройових сімей забезпечує високий рівень рентабельності за рахунок покращання епізоотичної ситуації та підвищення продуктив- 
ності бджіл. Саме тому чимало пасічників цікавиться ройовими матками, незважаючи на те, що виникнення в родинах стихійного роїння може виявитися збитковим для пасіки.

Схильність до рійливості у бджіл проявляється по-різному. Є сім’і, які з року в рік не рояться. Бджоли 3 молодими матками, особливо виводу весняно-літнього сезону, мають найменшу схильність до роїння або взагалі не рояться [2]. Передові пасічники, розуміючи, що для виникнення цього природного процесу необхідна поява якихось особливих умов, контролюють його $\mathrm{i}$ цілеспрямовано використовують ройові матки та маточники від високопродуктивної здорової

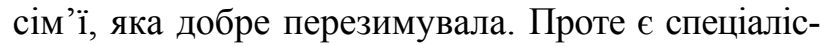
ти, які вважають недоцільним їх використання. Вбачаючи у здатності медоносних бджіл роїтися спадкові риси, вони обмежують використання на пасіках трутнів, маточників і маток від ройових сімей, хоч за науковими твердженнями такий вихідний племінний матеріал $є$ найвищої якості [2-5].

Утримання зимостійких сімей бджіл із різним способом розмноження, як і саме ройових маток у сім'ях із потенційно високою життєздатністю, викликає всебічний інтерес, однак до цього часу залишається не повністю вивченим і потребує подальших досліджень.

Мета досліджень та методика їх проведення. Визначення та порівняння показників біологічного потенціалу зимостійкості сімей із ройовими матками і робочих сімей, які впродовж минулорічного сезону не збуджувалися роїнням.

Дослідження проводилися на базі пасіки ВАТ «Полтава-племсервіс». Сім’ї бджіл, які впродовж торішнього пасічницького сезону не збуджувалися роїнням (контрольна група), випустили роя (дослідна перша група), були повернені до робочого стану (дослідна друга група) та родини бджіл, одержані 3 посаджених роїв (дослідна третя група), зрівнювали між собою за зимостійкістю (результатами зимівлі). Ї̈̈ характеризували за комплексом досліджуваних біологічних ознак: послабленням сили сімей (відхід бджіл), витратами корму на сім'ю і на вуличку зимувалих бджіл, ступіню опроношеності гнізд бджолиних сімей, кількістю розплоду в сім'ях бджіл на день першого весняного обліку. Враховували кількість сімей, що загинули або втратили маток під час зимівлі [2].

Результати досліджень. Найменший відхід бджіл після зимівлі виявлено у групі сімей, сформованих $з$ посаджених роїв. Різниця результатів відносно контрольної групи становила 45,28 \%. Більше бджіл втратила за зиму група 3 бджолиними сім'ями, які повернені до робочого стану застосуванням спеціальних прийомів бджоловедення. Різниця показника відносно контролю - 22,64 \%. Найбільше бджіл відійшло у материнських сім'ях, які в минулому році випустили роя. Відносно контролю різниця результату становила 1,8 \%. Проаналізувавши отримані нами результати відходу бджіл в абсолютних та відносних показниках, ми начислили наступне число балів відповідно по групах (див. рис.).

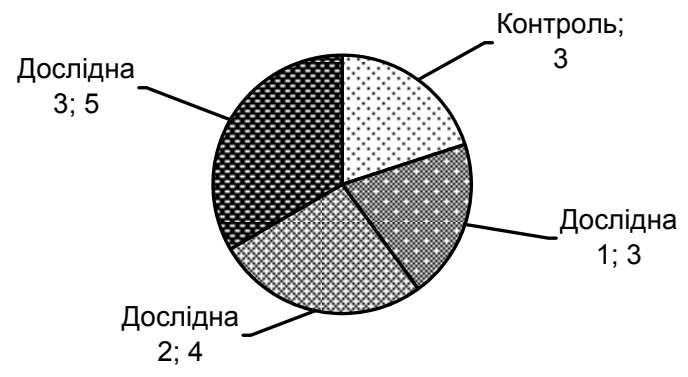

\section{Рис. Відхід бджіл у безоблітний період, бали}

При використанні описаного вище показника завжди варто пам'ятати, що невеликий відхід бджіл у зимовий період - закономірне біологічне явище. Тим паче, в сильних сім'ях (саме такими розпочинали зимівлю родини в наших дослідах), порівняно зі слабшими, завжди спостерігається більший абсолютний відхід бджіл у зимовий період. Для сильної сім'ї в 11-12 вуличок відхід бджіл у 2-3 вулички (близько 25 \%) не істотний і не впливає на їх подальший розвиток і життєдіяльність.

Важливим показником успішності зимівлі вважається витрата корму за весь іï період не тільки 3 позиції економії, а й поліпшення фізіологічного стану бджіл, бо чим менше вони споживали корм, тим менше в них було навантаження кишечників. Зима була досить тривалою й холодною, що призвело до збільшення витрат корму бджолами. Найменше корму витратили бджоли другої та третьої дослідних груп. У середньому на вуличку вони з'їли однакову його кількість: 2,25 кг (на 15,41 \% менше від контрольних; імовірність 95 \%). Дещо більше витраченого на вуличку бджіл корму було у дослідній першій групі: 2,50 кг (на 6,61% менше від контрольної).

Якщо судити про результат зимівлі лише за рівнем витрат корму, то можна стверджувати, що родини бджіл повернені з ройового до робочого стану та сформовані з посаджених роїв зимували задовільно. Їм начисляється по 3 бали в середньому на сім’ю. Погано зимували материнські сім’ї, які минулого сезону зроїлися (начислено 2 бали), та дуже погано, відповідно з нашим критерієм обліку, контрольні сім’ї бджіл (начислено 1 бал). 
СІЛЬСЬКЕ ГОСПОДАРСТВО. ТВАРИННИЦТВО

Комплексна оцінка зимостійкості бджолиних сімей піддослідних груп

\begin{tabular}{|c|c|c|c|c|}
\hline \multirow{2}{*}{ Показник } & \multicolumn{4}{|c|}{ Оцінка (бали) } \\
\cline { 2 - 5 } & контрольна & дослідна перша & дослідна друга & дослідна третя \\
\hline Сила сімей навесні & 4 & 4 & 4 & 5 \\
\hline Кількість спожитого корму & 1 & 2 & 3 & 3 \\
\hline Чистота гнізд & 4 & 4 & 5 & 5 \\
\hline Загальна оцінка & 9 & 10 & 12 & 13 \\
\hline До контролю, \% & 100 & 111,1 & 133,3 & 144,4 \\
\hline
\end{tabular}

Кожному пасічнику відомо, що гніздо бджіл і сам вулик мають бути чистими не лише $з$ естетичних міркувань. У пристосуванні бджіл переживати великий безоблітний період (від 4 до 7 місяців) і при цьому не спорожнити свої кишечники закладений глибокий біологічний зміст. Вважати, що сім'ї мають високу зимостійкість можна лише тоді, коли калове навантаження в їх кишечнику не переходить критичної точки, після якої бджоли починають опроношуватися. Судячи 3 кількості балів, нарахованих за чистоту гнізд (по чотири у контрольній та дослідній першій групах, і по п'ять у дослідних другій та третій групах), досліджувані бджолині сім’ї відзначаються високим потенціалом зимостійкості.

Бджолині сім'ї всіх піддослідних груп у обидва весняні періоди добре розвивалися. Висока енергія їх росту, що проявилася в стабілізації потенційної здатності до вирощування ранньовесняного розплоду в підготовчий період, майже без зменшення числа особин у сім'ї під час заміни зимувалих бджіл, є свідченням благополучної зимівлі. На період першого весняного обліку бджоли піддослідних груп при різній силі сімей виростили майже рівну кількість розплоду. Винятком стали родини 3 посаджених роїв, які мали розплоду на $9 \%$ більше, ніж контрольні. Впродовж весняного періоду сім'ї бджіл усіх груп мали в гнізді стабільно динамічне збільшення його кількості. Сила сімей бджіл на цей час була більшою в досліді, ніж у контролі:

\section{БІБЛІОГРАФІЯ}

1. Бабич И. А., Мегедь А. Г. Пчеловодство: учеб. [для уч. сред. спец. науч. завед.] / И. А. Бабич, А. Г. Мегедь. - К. : Урожай, 1973. - 344 с.

2. Гречка Г. М. Технологічна інструкція направленого використання бджолиних сімей зі зміненим фізіологічним станом / Г. М. Гречка. - Гадяч. ННЦ «Інститут бджільництва ім. П. І. Прокоповича». $-2010 .-50 \mathrm{c}$. на 5,74 \% у першій групі, на 17,14 \% - у другій i на $34,14 \%$ - у третій групі. Остання різниця наближена до високоімовірної $(\mathrm{P}<0,01)$.

Сильні бджолині сім’ї на час весняної ревізії це свідчення високого потенціалу їх життєздатності, завдяки якому можна прогнозувати збереження бджолами нового покоління кращих ознак дворічних маток позаминулого року виведення.

Не дивлячись на тривалий перебіг безоблітного періоду (понад 160 днів), зимівля бджолиних сімей пройшла задовільно. Краще перезимували родини 3 посаджених роїв. 3 комплексного оцінювання зимостійкості кращий результат відносно контролю одержано в сім'ях із ройовими матками. У відсотках різниця показників до контролю відповідно по групах становить: 44,4 родини 3 посаджених роїв, 33,3 - повернені до робочого стану і 11,1 - материнські родини, які роїлися (див. табл.).

Висновки. Збережені в зимовий період бджолині сім'ї з ройовими матками, як і з матками штучного виведення, є життєздатними. Аналіз результатів зимівлі бджіл піддослідних груп свідчить про високу зимостійкість і найвищий потенціал життєздатності в сім'ях із ройовими матками. За комплексом біологічних ознак загальна різниця балів родин із посаджених роїв, повернених до робочого стану, материнських, що зроїлися, до незбуджених роїнням склала, відповідно, 44,4; 33,3; 11,1 (\%).

3. Малков В. В. Племенная работа на пасеке / В. В. Малков. - М. : Россельхозиздат, 1985. - 176 с. 4. Полішук В. П. Бджільництво : підруч. [для науковців, студ. вищ. навч. закл.] / В. П. Поліщук. - Л. : Український пасічник, 2001. - 296 с.

5. Чергик M. I. Вплив роїння на медозбір. Весняний розвиток бджоли / М. І. Чергик // Пасіка. 2003. - №3. - C. 8-9. 